\title{
E-GOVERNMENT DALAM PENYELENGGARAAN PEMERINTAHAN DAERAH DI INDONESIA
}

\author{
Titon Slamet Kurnia, Umbu Rauta, Arie Siswanto \\ Fakultas Hukum Universitas Kristen Satya Wacana \\ Jalan Diponegoro 52-60 Salatiga, Jawa Tengah, 50711 \\ titonslamet@gmail.com; umburauta@yahoo.com; ariesiswanto@yahoo.com
}

\begin{abstract}
This paper examines the utilization of E-Government (Electronic Government) in the local governance in Indonesia from juridical perspective. Juridical aspects discussed include: theoretical foundation, superstructure support in the form of existing arrangements at national or central level, as well as suggestions for the regions in order to implement the E-Government, particularly in terms of the legal framework as the initial base. This paper is a result of a legal research using both theoretical-conceptual and statute approach.
\end{abstract}

Keywords: E-Government, local governance

\begin{abstract}
Abstrak
Tulisan ini hendak mengkaji pemanfaatan E-Government (Electronic Government) dalam penyelenggaraan pemerintahan daerah di Indonesia dengan menggunakan perspektif yuridis. berupa pengaturan yang sudah ada pada tingkat nasional atau pusat serta saran tindak bagi daerah dalam rangka mengimplementasikan E-Government, terutama pijakan awalnya berupa suatu kerangka hukum (legal framework). Tulisan ini merupakan penelitian hukum dengan menggunakan pendekatan teoretis-konseptual (conceptual approach) dan pendekatan perundang-undangan (statute approach).
\end{abstract}

Kata-kata Kunci: E-Government; pemerintahan daerah

\section{A. Pendahuluan}

1. Latar Belakang Permasalahan

Teknologi informasi dan komunikasi

(TIK) atau Information Communication Technology (ICT), khususnya internet, merevolusi cara hidup manusia pada abad ke21 ini. Pro-kontra, dampak positif-negatif, tentu selalu ada. Tetapi, saat ini, tidak ada satupun aspek kehidupan kita yang jauh dari TIK, terutama internet.

Pe manfaatan TIK d a lam penyelenggaraan pemerintahan termasuk salah satu fenomena penting pada abad ke-21 ini, yang mampu mengubah 'wajah' pelayanan pemerintah kepada masyarakat. Oleh karena itu berkembang konsep $E$ Government di mana secara konseptual perkembangannya nampak tergambar melalui kutipan berikut: "For more than 10 years, expectations about the Internet's potential to change the relations between citizens and their governments at the political, democratic level and with regard to public services for citizens and business have been high." (H. Kubicek, 2011)

Tulisan ini hendak mengkaji pemanfaatan E-Government (Electronic Government) dalam penyelenggaraan pemerintahan daerah di Indonesia dengan menggunakan perspektif yuridis. Cikal bakal dari konsep E-Government di Indonesia adalah Instruksi Presiden Republik Indonesia (Inpres) Nomor 3 Tahun 2003 tentang Kebijakan dan Strategi Nasional Pengembangan E-Government. Dalam perkembangannya, konsep E-Government tersebut didefinisikan: "pemanfaatan Teknologi Informasi dan Komunikasi (TIK)

\footnotetext{
* Artikel ini merupakan hasil penelitian yang dikembangkan dari penyusunan Naskah Akademik dan Raperda Kota Salatiga tentang E-Government dengan sumber pembiayaan Anggaran Pendapatan dan Belanja Daerah Kota Salatiga (2016).
} 
dalam penyelenggaraan sistem elektronik untuk pelayanan publik dan administrasi pemerintahan (untuk selanjutnya disebut Sistem Elektronik Pemerintahan atau disingkat SEP) (Naskah Akademik Rancangan Undang-Undang)." Definisi tersebut sejalan dengan definisi E-Government di Amerika Serikat yang dicanangkan oleh the U.S. Electronic Government Act of 2002:

the use by the Government of webbased Internet applications and other information technologies, combined with processes that implement these technologies, to - (A) enhance the access to and delivery of Government information and services to the public, other agencies, and other Government entities; or (B) bring about improvements in Government operations that may include effectiveness, efficiency, service quality, or transformation.

Definisi menurut the U.S. Electronic Government Act of 2002 relatif lebih lengkap karena juga menyinggung isu aspek kemanfaatan dari penyelenggaraan $E$ Government yang arahnya adalah untuk membawa perbaikan-perbaikan dalam penyelenggaraan pemerintahan yang meliputi: efektivitas, efisiensi dan kualitas dalam pemberian pelayanan.

Saat ini, pemanfaatan TIK telah berkembang semakin masif. Oleh karena itu, mendiskusikan pemanfaatan E-Government dalam penyelenggaraan pemerintahan daerah tentu sejalan pula dengan semangat zaman. Berdasarkan pemahaman tersebut maka penulis akan mengelaborasi aspek-aspek yuridis yang relevan dalam pengembangan $E$ Government dalam rangka penyelenggaraan pemerintahan daerah di Indonesia. Aspekaspek yuridis yang dibicarakan meliputi: landasan teoretisnya, dukungan suprastruktur berupa pengaturan yang sudah ada pada tingkat nasional atau pusat serta saran tindak b a g i d a rah da 1 a m ra n g a mengimplementasikan E-Government, terutama pijakan awalnya berupa suatu kerangka hukum (legal framework). Sesuai dengan pemahaman tersebut maka tulisan ini hendak berargumen mendukung supaya daerah mengimplementasikan E-Government dalam penyelenggaraan pemerintahan daerah serta upaya hukum yang seyogianya dilakukan dalam mengimplementasikan $E$ Government tersebut.

\section{Permasalahan}

Berdasarkan penjelasan yang telah dikemukakan di atas maka ada tiga masalah yang hendak dibahas oleh tulisan ini. yaitu:

1. apakah landasan teoretis untuk $E$ Government dalam penyelenggaraan pemerintahan daerah?

2. Apakah E-Government dalam penyelenggaraan pemerintahan daerah sudah didukung oleh kerangka hukum yang memadai?

3. Apakah yang harus dilakukan daerah dalam mengimplementasikan $E$ Government dalam penyelenggaraan pemerintahan daerah?

\section{Metode Penelitian}

Tulisan ini merupakan hasil dari penelitian hukum (legal research) dengan menggunakan pendekatan teoretiskonseptual (conceptual approach) dan pendekatan perundang-undangan (statute approach). Itu artinya, permasalahan yang dirumuskan di atas berusaha untuk dijawab atau diberikan pendapat secara hukum dengan berbasis atau mengacu pada sumbersumber hukum yang meliputi doktrin/pendapat-pendapat sarjana di bidang I $1 \mathrm{mu} \mathrm{Hukum} \mathrm{(khususnya} \mathrm{Hukum}$ Administrasi) serta peraturan perundangundangan.

\section{Kerangka Teori}

Kerangka teori yang digunakan oleh penelitian ini adalah adaptasi konsepsi Hukum Administrasi terhadap perkembangan TIK yang berimplikasi mendorong perubahan dalam teknik penyelenggaraan pemerintahan dengan menggunakan TIK (E-Government). Pada prinsipnya, hukum harus senantiasa menyesuaikan diri dengan dinamika kemasyarakatan karena hukum berfungsi merespons dinamika tersebut dengan jalan menetapkan suatu preskripsi. Salah satu dinamika kemasyarakatan paling penting adalah penggunaan TIK, khususnya internet, secara meluas. Untuk itu hukum (termasuk 
Hukum Administrasi) bertanggung jawab untuk mengatur penggunaan dan penyalahgunaan teknologi serta jangkauan aplikasinya (N. Lucchi, 2016).

Semua produk teknologi pasti memiliki dampak positif dan negatif, termasuk TIK (K.D. Pimple, 2014). Hal prinsipnya sebagaimana ditekankan oleh Lucchi adalah: "Continuing advances in scientific and technological innovations are essential to modern societies. Historically, such developments had improved living conditions in both developed and developing countries. Understanding their function and regulation means defining and clarifying the relationship between science and technology advances and society's ability to benefit from it." (N. Lucchi, 2016) Oleh karena itu, sependapat dengan Lucchi, perlu pemahaman mengenai dampak positif dari teknologi sehingga pengaturan pemanfaatannya mampu berdampak menguntungkan. Dalam rangka penyelenggaraan pemerintahan, pemanfaatan TIK diyakini lebih banyak sisi positifnya. Karena itu, Hukum Administrasi sebagai hukum yang mendasari beroperasinya suatu pemerintahan perlu mendorong pemanfaatan TIK dalam penyelenggaraan pemerintahan, termasuk pada pemerintahan daerah.

\section{B. Pembahasan \\ 1. Konsepsi Hukum Administrasi Baru dan E-Government}

Landasan teoretis untuk pengimplementasian E-Government dalam penyelenggaraan pemerintahan daerah adalah konsepsi Hukum Administrasi Baru (New Administrative Law) yang lebih menekankan pada isu-isu kontemporer seperti perlunya akuntabilitas dan efisiensi pemerintahan. Konsepsi Hukum Administasi Baru ini secara simbolis biasa disebut dengan istilah Good Governance atau Good Administration.

Seperti sudah menjadi pengetahuan umum bahwa konsep good governance pada mulanya merupakan bentuk pensyaratan (conditionalities) yang diajukan oleh lembaga keuangan internasional dan negaranegara kreditur kepada negara-negara debiturnya (M. Kjaer \& K. Kinnerup, 2002). Motif mereka menuntut pemberlakuan good governance kepada negara-negara debitur sangat jelas yaitu agar kredit mereka 'aman'. Akan tetapi, cara pandang politis a priori demikian tentu tidak dapat begitu saja diterima karena konsep good governance sendiri sebenarnya secara intrinsik memiliki makna atau pengertian yang positif secara kontekstual. Dalam perspektif demikian, konsep good governance lebih banyak sisi positifnya ketika diberlakukan sebagai asas atau prinsip hukum yang mendasari hubungan antara pemerintah dengan rakyat atau warga negara ketimbang sebaliknya. Hal ini sejalan dengan mission statement Hukum Administrasi yang dikemukakan oleh Cane yaitu: "the main significance of administrative law norms is not that they provide standards for dealing with bad administration but that they help to define, encourage, and promote good administration." (P. Cane, 2011).

Sisi positif inheren dalam konsep good governance nampak dalam penjelasan Bank Dunia (the World Bank) yang memberikan indikator sebagai kriteria untuk good governance sebagai berikut: "predictable, enlightened and open policyprocesses, bureaucracy with a professional ethos, a government accountable for its actions, a strong civil society participating actively in public affairs, and all under the rule of law." (World Bank, 1994) Berdasarkan kriteria tersebut maka konsep good governance dapat diterima secara objektif sebagai syarat yang memang di dalamnya mengandung sisi-sisi positif inheren.

Secara yuridis, dalam konteks Indonesia, restatement asas-asas atau prinsipprinsip good governance sebagai bestursnormen (norma-norma atau kaidahkaidah pemerintahan) telah dilakukan melalui Undang-Undang Nomor 30 Tahun 2014 tentang Administrasi Pemerintahan (UU No. 30 Tahun 2014). Hal itu tercermin dari, pertama, maksud diberlakukannya UU No. 30 Tahun 2014 sebagai dasar hukum bagi badan dan/atau pejabat pemerintahan, warga masyarakat, dan pihak-pihak lain yang terkait dengan administrasi pemerintahan dalam upaya meningkatkan kualitas penyelenggaraan pemerintahan (Pasal 2 UU No. 
30 Tahun 2014). Kedua, tujuan diberlakukannya UU No. 30 Tahun 2014, yaitu: menciptakan tertib penyelenggaraan administrasi pemerintahan; menciptakan kepastian hukum; mencegah terjadinya penyalahgunaan wewenang; menjamin akuntabilitas badan dan/atau pejabat pemerintahan; memberikan perlindungan hukum kepada warga masyarakat dan aparatur pemerintahan; melaksanakan ketentuan peraturan perundang-undangan dan menerapkan asas-asas umum pemerintahan yang baik; memberikan pelayanan yang sebaik-baiknya kepada warga masyarakat (Pasal 3 UU No. 30 Tahun 2014).

Selain segi keabsahan hukum (rechtmatigheid), kinerja pemerintah dalam penyelenggaraan pemerintahan juga lazim dinilai berdasarkan parameter efisiensi dan efektivitasnya (doelmatigheid) (P.M. Hadjon, 1987). Asas efisiensi dan efektivitas pemerintahan berkaitan dengan apakah tindak pemerintahan berhasil mencapai tujuan/sasarannya atau tidak; apakah hasil yang diperoleh sepadan dengan biaya yang ditanggung; apakah tindakan tersebut tidak terhindarkan; atau apakah masih ada alternatif lainnya dengan hasil yang lebih baik (K.D. Darumurti, 2012). Dalam konteks asas good governance, efisiensi dan efektivitas pemerintahan adalah alasan substantif di balik pentingnya keterbukaan atau transparansi pemerintahan karena hal itu yang memberikan peluang sebesar-besarnya untuk partisipasi masyarakat dalam pemerintahan.

Akan tetapi, lebih jauh lagi, aspek keekonomian dalam penyelenggaraan pemerintahan juga dapat berposisi sebagai variabel mandiri dalam rangka pencapaian efisiensi dan efektivitas pemerintahan. Dengan keterbatasan sumber daya maka perilaku tidak efisien dan tidak efektif dari pemerintah adalah praktik pemerintahan yang tidak bermoral (H. McCoubrey \& N.D. White). Saat sekarang, isu tersebut kembali bergema dengan slogan Joko Widodo, Presiden ke-7 Republik Indonesia, yang dikenal dengan 'revolusi mental'.

Hubungan antara instrumentalisasi $E$ Government dalam penyelenggaraan pemerintahan dengan asas-asas atau prinsipprinsip good governance sebagai tolok ukur yuridis dalam penyelenggaraan pemerintahan menjadi jelas, yaitu untuk memperbaiki kualitas kinerja pemerintah. Secara lebih spesifik, dalam konteks asas-asas dan prinsipprinsip good governance, perbaikan kualitas kinerja pemerintah harus didorong salah satunya dalam bentuk kepatuhan terhadap asas keterbukaan/transparansi pemerintahan dan asas efisiensi-efektivitas pemerintahan. Berdasarkan pemahaman demikian maka instrumentalisasi sistem elektronik dalam penyelenggaraan pemerintahan diharapkan dapat mendorong atau meningkatkan keterbukaan dan efisiensi-efektivitas pemerintahan supaya tuntutan asas-asas atau prinsip-prinsip good governance dapat diwujudkan.

Keterbukaan dalam akses informasi publik hanya salah satu aspek saja dalam menjawab persoalan keterbukaan atau transparansi pemerintahan secara umum. Akan tetapi dapat juga dipahami di sini bahwa keterbukaan atas akses informasi publik dapat bermakna sebagai starting point untuk keterbukaan atau transparansi pemerintahan secara umum. Dalam pengertian demikian maka keterbukaan informasi publik menjadi sangat penting sebagai bagian dari keterbukaan atau transparansi pemerintahan secara umum (R. Douglas,1998).

Keterbukaan atau transparansi pemerintahan dapat mendorong akuntabilitas pemerintahan merupakan isu sangat penting dalam demokrasi, terutama gagasan pemerintahan untuk rakyat. Proses pengawasan terhadap jalannya pemerintahan supaya hasil-hasil dari pemerintahan benarbenar dapat dinikmati rakyat hanya dapat dikondisikan oleh keterbukaan atau transparansi pemerintahan. Dengan pengertian ini maka keterbukaan atau transparansi pemerintahan akan memudahkan pengawasan oleh rakyat terhadap pemerintahnya sehingga dapat mendorong proses akuntabilitas pemerintahan semakin lebih baik.

Instrumentalisasi sistem elektronik untuk penyelenggaraan pemerintahan $(E-$ 
Government) diharapkan mampu menjawab isu akuntabilitas pemerintahan sehingga kepatuhan pemerintah terhadap asas efisiensi dan efektivitas pemerintahan dapat terjadi. Tentang hubungan langsung antara instrumentalisasi sistem elektronik untuk penyelenggaraan pemerintahan dengan efisiensi Kubicek et.al., secara eksplisit menyatakan: "By providing public services via the Internet, it was thought that public services would become more customercentered and efficient." (H. Kubicek, 2011) Keyakinan senada, dan lebih luas, juga disampaikan oleh European Commission tentang manfaat dari E-Government yaitu: "More open and transparent, reinforcing democratic participation; More serviceoriented, providing personalized and inclusive services to each citizen; More productive, delivering maximum value for taxpayers' money." (H. Kubicek, 2011).

Menyimak pandangan di atas, awal mula munculnya gagasan E-Government, sasaran yang hendak dicapai ialah memaksimalkan pelayanan pemerintahan atau pelayanan publik kepada masyarakat sebagai konsumen (pengguna). Posisi masyarakat sebagai konsumen (pengguna) pelayanan pemerintahan menggerakkan pemerintah untuk mengupayakan supaya proses dan produk pelayanan pemerintahan efisien dan efektif. Faktor utama dari efisiensi adalah penggunaan sumber daya secara terkendali dalam memberikan dan menghasilkan jasa pelayanan pemerintahan, termasuk meminimalisir beban-beban yang tidak perlu di pihak masyarakat. Sementara faktor utama dari efektivitas adalah pelayanan pemerintahan atau pelayanan publik yang diberikan memang tepat sesuai dengan kebutuhan masyarakat. Instrumentalisasi sistem elektronik untuk penyelenggaraan pemerintahan diyakini mampu menjawab kebutuhan terkait efisiensi dan efektivitas dalam penyelenggaraan pemerintahan. Kesadaran demikian tidak terlepas dari kepercayaan terhadap teknologi informasinya itu sendiri sehingga atas dasar kepercayaan tersebut akhirnya dikembangkan model E-Government.

Efisiensi dan efektivitas pemerintahan pada hakikatnya merupakan konsekuensi logis dari instrumentalisasi E-Government. Terkait dengan keterbukaan atau ransparansi pe merintahan, E-Governme $n t$ mengkondisikan timbulnya keterbukaan atau transparansi pemerintahan sehingga dengan pra-kondisi tersebut maka diharapkan akan meningkatkan partisipasi masyarakat dalam pemerintahan. Meningkatnya partisipasi masyarakat dalam pemerintahan akan berimplikasi pada efisiensi dan efektivitas pemerintahan (B. So, 2003).

Lebih jauh lagi, sebagai sebuah produk teknologi yang sifatnya mempermudah pekerjaan manusia, $E$ Government juga memiliki karakter inheren untuk cenderung menciptakan penghematanpenghematan secara ekonomis. Oleh karena itu, berdasarkan pembahasan di atas nampak bahwa E-Government konsisten dalam mendukung penyelenggaraan pemerintahan berdasarkan asas-asas atau prinsip-prinsip good governance, yaitu untuk mendorong transparansi/keterbukaan pemerintahan dan untuk mendorong efisiensi-efektivitas kinerja pemerintah. Dalam konteks demikian, pandangan Organization for Economic and Co-operation and Development (OECD) yang menyatakan bahwa "Open government means cleaner government. Openness in government enables effective public scrutiny which, in turn, helps to achieve and maintain high standards of integrity in the public sphere" (OECD Guiding Principles, 2010) juga berlaku secara mutatis mutandis terhadap isu instrumentalisasi sistem elektronik untuk penyelenggaraan pemerintahan ( $E$ Government).

\section{Kerangka Peraturan Perundang- undangan Terkait dengan $E$ - Government}

Pengimplementasian E-Government dalam penyelenggaraan pemerintahan pada hakikatnya telah ditunjang oleh keberadaan peraturan perundang-undangan pada tingkat nasional, meskipun belum ada undangundang yang secara khusus mengatur tentang E-Government (Keinginan untuk mengadakan undang-undang). Bagian ini akan menjelaskan materi muatan peraturan perundangundangan existing yang mendukung 
pengimplementasian E-Government dalam penyelenggaraan pemerintahan secara umum, dan dalam penyelenggaraan pemerintahan daerah secara khusus.

Perihal kewenangan dan tanggung jawab penyelenggaraan E-Government di daerah dapat diperhatikan dalam Pasal 12 ayat (2) huruf j Undang-Undang Nomor 23 Tahun 2014 tentang Pemerintahan Daerah (UU No. 23 Tahun 2014), yang di dalamnya mengatur tentang salah satu urusan (baca: kewenangan) pemerintahan wajib yang tidak berkaitan dengan pelayanan dasar yaitu komunikasi dan informatika. Selanjutnya dalam Lampiran huruf P UU No. 23 Tahun 2014 yang mengatur tentang pembagian urusan pemerintahan antara pemerintah pusat, provinsi dan kabupaten/kota, penyelenggaran E-Government diletakkan sebagai SubUrusan dari Urusan Komunikasi dan Informatika, yaitu sub-urusan Aplikasi Informatika. Dalam sub-urusan aplikasi informatika tersebut, ranah kewenangan kabupaten/kota berkenaan atau mencakup: (1) pengelolaan nama domain yang telah ditetapkan oleh Pemerintah Pusat dan sub domain di lingkup Pemerintah Daerah kabupaten/kota; dan (2) Pengelolaan EGovernment di lingkup Pemerintah Daerah kabupaten/kota.

Ketentuan lain dalam UU No. 23 Tahun 2014 yang terkait dengan penyelenggaraan E-Government diatur dalam Pasal 345 dan Pasal 391-394. Pasal 345 UU No. 23 Tahun 2014 mengatur tentang manajemen pelayanan publik, di mana pada ayat (1) ditegaskan bahwa Pemerintah Daerah wajib membangun manajemen pelayanan publik dengan mengacu pada asas-asas pelayanan publik. Manajemen pelayanan publik meliputi: pelaksanaan pelayanan; pengelolaan pengaduan masyarakat; pengelolaan informasi; pengawasan internal; penyuluhan kepada masyarakat; pelayanan konsultasi; dan pelayanan publik lainnya sesuai dengan ketentuan peraturan perundang-undangan.

Selanjutnya dalam Pasal 391-394 UU No. 23 Tahun 2014 diatur tentang Informasi Pemerintahan Daerah. Pasal 391 UU No. 23
Tahun 2014 mengatur bahwa Pemerintah Daerah wajib menyediakan informasi Pemerintahan Daerah yang terdiri atas: informasi pembangunan Daerah; dan informasi keuangan Daerah. Informasi Pemerintahan Daerah dikelola dalam suatu sistem informasi Pemerintahan Daerah. Informasi pembangunan Daerah sebagaimana diatur dalam Pasal 391 memuat informasi perencanaan pembangunan Daerah yang mencakup: kondisi geografis Daerah; demografi; potensi sumber daya Daerah; ekonomi dan keuangan Daerah; aspek kesejahteraan masyarakat; aspek pelayanan umum; dan aspek daya saing Daerah (Pasal 392 UU No. 23 Tahun 2014).

Kemudian Informasi keuangan Daerah paling sedikit memuat informasi anggaran, pelaksanaan anggaran, dan laporan keuangan (Pasal 393 UU No. 23 Tahun 2014). Informasi keuangan Daerah digunakan untuk: (a) membantu kepala daerah dalam menyusun anggaran daerah dan laporan pengelolaan keuangan daerah; (b) membantu kepala daerah dalam merumuskan kebijakan keuangan daerah; (c) membantu kepala daerah dalam melakukan evaluasi kinerja keuangan daerah; (d) membantu menyediakan kebutuhan statistik keuangan daerah; (e) mendukung keterbukaan informasi kepada masyarakat; (f) mendukung penyelenggaraan sistem informasi keuangan daerah secara nasional; dan (g) melakukan evaluasi pengelolaan keuangan daerah.

Selain pengaturan dalam UU No. 23 Tahun 2014, pengaturan mengenai penyelenggaraan sistem elektronik di lingkungan pemerintahan daerah juga diatur dalam Pasal 7 Undang-Undang Nomor 14 Tahun 2008 tentang Informasi dan Transaksi Elektronik (UU No. 14 Tahun 2008). Dalam ketentuan tersebut, Pasal 7 UU No. 14 Tahun 2014, Badan Publik (termasuk Pemerintahan Daerah) wajib menyediakan, memberikan dan/atau menerbitkan Informasi Publik yang berada di bawah kewenangannya kepada Pemohon Informasi Publik, selain informasi yang dikecualikan. Badan Publik wajib menyediakan Informasi Publik yang akurat, benar, dan tidak menyesatkan. Untuk 
melaksanakan kewajiban (menyediakan, memberikan dan/atau menerbitkan Informasi Publik), Badan Publik harus membangun dan mengembangkan sistem informasi dan dokumentasi untuk mengelola Informasi Publik secara baik dan efisien sehingga dapat diakses dengan mudah. Dalam rangka memenuhi kewajibannya, Badan Publik dapat memanfaatkan sarana dan/atau media elektronik dan non-elektronik.

Lebih lanjut dalam Pasal 4 UU No. 14 Tahun 2008 ditegaskan bahwa pemanfaatan Teknologi Informasi dan Transaksi Elektronik dilaksanakan dengan tujuan untuk:

a. mencerdaskan kehidupan bangsa sebagai bagian dari masyarakat informasi dunia;

b. mengembangkan perdagangan dan perekonomian nasional dalam rangka meningkatkan kesejahteraan masyarakat;

c. meningkatkan efektivitas dan efisiensi pelayanan publik;

d. membuka kesempatan seluas-luasnya kepada setiap orang untuk memajukan pemikiran dan kemampuan di bidang penggunaan dan pemanfaatan Teknologi Informasi seoptimal mungkin dan bertanggung jawab; dan

e. memberikan rasa aman, keadilan, dan kepastian hukum bagi pengguna dan penyelenggara Teknologi Informasi.

Mengacu pada tujuan penyelenggaraan informasi dan transaksi elektronik, Pemerintah dan Masyarakat mempunyai peran sebagaimana diatur dalam Pasal 40 UU No. 14 Tahun 2008. Dalam pasal tersebut dinyatakan bahwa Pemerintah (Pusat) memfasilitasi pemanfaatan Teknologi Informasi dan Transaksi Elektronik sesuai dengan ketentuan Peraturan Perundangundangan. Pemerintah melindungi kepentingan umum dari segala jenis gangguan sebagai akibat penyalahgunaan Informasi Elektronik dan Transaksi Elektronik yang mengganggu ketertiban umum, sesuai dengan ketentuan Peraturan Perundang-undangan. Pemerintah menetapkan instansi atau institusi yang memiliki data elektronik strategis yang wajib dilindungi. Instansi atau institusi tersebut harus membuat Dokumen Elektronik dan rekam cadang elektroniknya serta menghubungkannya ke pusat data tertentu untuk kepentingan pengamanan data. Instansi atau institusi lain membuat Dokumen Elektronik dan rekam cadang elektroniknya sesuai dengan keperluan perlindungan data yang dimilikinya.

Terkait dengan penggunaan Sistem Elektronik dalam konteks pelayanan publik, terdapat ketentuan yang relevan di dalam Peraturan Pemerintah No. 82 Tahun 2012 tentang Penyelenggaraan Sistem dan Transaksi Elektronik (PP No. 82 Tahun 2012) yang mewajibkan Penyelenggara Sistem Elektronik untuk pelayanan publik untuk melakukan pendaftaran pada Menteri yang menyelenggarakan urusan pemerintahan di bidang komunikasi dan informatika, sebelum Sistem Elektronik mulai digunakan publik (Pasal 5 ayat (1) dan (3) PP No. 82 Tahun 2012). Hal paling fundamental dalam menentukan kinerja E-Government ini adalah tata-kelola teknologi informasi. Untuk mewujudkan tatakelola yang baik, ada beberapa unsur yang perlu diperhatikan, yaitu: (1) penyelenggara Sistem Elektronik; (2) prinsip-prinsip penyelenggaraan Sistem Elektronik; dan (3) cakupan penyelenggaraan Sistem Elektronik.

Penentuan tentang siapa yang bertanggung jawab menjadi penyelenggara Sistem Elektronik merupakan langkah yang amat penting mengingat bahwa unsur penyelenggara Sistem Elektronik menempati posisi strategis dalam penyelenggaraan Sistem Elektronik dalam Pemerintahan Daerah. Sejauh ini tidak ada peraturan perundang-undangan yang secara umum memuat ketentuan tentang penyelenggara sistem elektronik. Meski demikian, secara nalar dapat dikemukakan bahwa setidaknya ada tiga pihak yang relevan dalam penyelenggaraan Sistem Elektronik, yaitu unit kerja di setiap SKPD, Diskominfo serta pihak eksternal yang mungkin dilibatkan dalam penyelenggaraan Sistem Elektronik.

Secara ideal, memang sebaiknya di setiap SKPD dibentuk unit kerja untuk menangani sistem elektronik di lingkungan SKPD masing-masing. Unit kerja ini 
diperlukan dengan rasionalisasi bahwa SKPD semestinya menjadi pihak yang bertanggungjawab atas pengelolaan data dan sistem informasi di lingkungan SKPD masing-masing. Meski demikian, karena Sistem Elektronik diharapkan terintegrasi, te tap dibutuhkan pihak yang bertanggungjawab untuk mengelola pusat data dan mengkonsolidasikan data dari SKPD. Sesuai dengan teba tugas dan fungsinya, pihak yang harus menjadi leading unit dalam pengelolaan Sistem Elektronik adalah Dinas Komunikasi dan Informasi (Diskominfo). Ada kemungkinan pula pihak ketiga/pihak eksternal di luar Pemerintah Daerah terlibat dalam pengelolaan Sistem Elektronik. Dalam hal demikian, prinsip yang harus dipegang teguh adalah bahwa pihak eksternal ini berada di bawah kendali Pemerintah Daerah.

Pengaturan tentang penyelenggara Sistem Elektronik yang berkenaan dengan tata-kelola penyelenggaraan terdapat dalam PP No. 82 Tahun 2012, khususnya di Bagian Keenam tentang tata Kelola Sistem Elektronik. Beberapa ketentuan yang relevan adalah sebagai berikut:

a. Penyelenggara Sistem Elektronik wajib menjamin: (a) tersedianya perjanjian tingkat layanan; (b) tersedianya perjanjian keamanan informasi terhadap jasa layanan Teknologi Informasi yang digunakan; dan (c) keamanan informasi dan sarana komunikasi internal yang diselenggarakan (Pasal 12 ayat (1) PP No. 82 Tahun 2012).

b. Penyelenggara Sistem Elektronik wajib menjamin setiap komponen dan keterpaduan seluruh Sistem Elektronik beroperasi sebagaimana mestinya (Pasal 12 ayat (2) PP No. 82 Tahun 2012).

c. Penyelenggara Sistem Elektronik wajib menerapkan manajemen risiko terhadap kerusakan atau kerugian yang ditimbulkan (Pasal 13 PP No. 82 Tahun 2012)..

d. Penyelenggara Sistem Elektronik wajib memiliki kebijakan tata kelola, prosedur kerja pengoperasian, dan mekanisme audit yang dilakukan berkala terhadap Sistem Elektronik (Pasal 14 ayat (1) PP
No. 82 Tahun 2012).

e. Penyelenggara Sistem Elektronik wajib: (a) menjaga rahasia, keutuhan, dan ketersediaan Data Pribadi yang dikelolanya; (b) menjamin bahwa perolehan, penggunaan, dan pemanfaatan Data Pribadi berdasarkan persetujuan pemilik Data Pribadi, kecuali ditentukan lain oleh peraturan perundang-undangan; dan (c) menjamin penggunaan atau pengungkapan data dilakukan berdasarkan persetujuan dari pemilik Data Pribadi tersebut dan sesuai dengan tujuan yang disampaikan kepada pemilik Data Pribadi pada saat perolehan data (Pasal 15 ayat (1) PP No. 82 Tahun 2012).

Di samping ketentuan yang bersifat umum tersebut, khusus bagi penyelenggara Sistem Elektronik untuk pelayanan publik juga harus memenuhi kewajiban menerapkan tata kelola yang baik dan akuntabel. Kriteria "baik dan akuntabel" (Pasal 16 ayat (1) PP No. 82 Tahun 2012). selanjutnya dimaknai sebagai kondisi yang memenuhi persyaratan sebagai berikut:

a. tersedianya prosedur atau petunjuk dalam Penyelenggaraan Sistem Elektronik yang didokumentasikan dan/atau diumumkan dengan bahasa, informasi, atau simbol yang dimengerti oleh pihak yang terkait dengan Penyelenggaraan Sistem Elektronik tersebut;

b. adanya mekanisme yang berkelanjutan untuk menjaga kebaruan dan kejelasan prosedur pedoman pelaksanaan;

c. adanya kelembagaan dan kelengkapan personel pendukung bagi pengoperasian Sistem Elektronik sebagaimana mestinya;

d. adanya penerapan manajemen kinerja pada Sistem Elektronik yang diselenggarakannya untuk memastikan Sistem Elektronik beroperasi sebagaimana mestinya; dan

e. adanya rencana menjaga keberlangsungan Penyelenggaraan Sistem Elektronik yang dikelolanya (Pasal 16 ayat (2) PPNo. 82 Tahun 2012). 
Dalam kerangka tata-kelola Sistem Elektronik, perlu ditegaskan prinsip-prinsip yang diterapkan. Untuk itu, prinsip-prinsip yang termuat di dalam berbagai peraturan perundang-undangan yang relevan bisa diadopsi untuk diterapkan dalam penyelenggaraan Sistem Elektronik oleh Pemerintahan Daerah. Prinsip-prinsip tersebut adalah:

a. Prinsip efisiensi mengandung makna bahwa penerapan Sistem Elektronik untuk mendukung penyelenggaraan pemerintahan daerah harus menciptakan efisiensi secara signifikan terutama di dalam mendukung kecepatan dan kesederhanaan layanan publik.

b. Prinsip transparansi yang menghendaki agar penyelenggaraan Sistem Elektronik dilakukan secara terbuka, terutama ketika menyangkut pelayanan publik.

c. Prinsip reliabilitas yang menghendaki jaminan keandalan data menyangkut kebenaran dan akurasi data yang disajikan dalam kerangka penyelenggaraan Sistem Elektronik dalam Pemerintahan Daerah serta keandalan sistem menyangkut kualitas sistem elektronik beserta komponen-komponen pendukungnya yang membuat sistem elektronik dapat berjalan dengan baik serta mudah digunakan.

d. Prinsip interkonektivitas yang menghendaki agar Sistem Elektronik yang diaplikasikan dalam penyelenggaraan Pemerintahan Daerah dapat terhubung dengan sistem yang lebih luas serta menyatu dengan sistem yang lebih luas. Prinsip ini antara lain tercermin dari persyaratan perangkat keras yang harus, "memenuhi aspek interkonektivitas dan kompatibilitas dengan sistem yang digunakan." "Interkonektivitas" sendiri dipahami sebagai kemampuan untuk terhubung satu sama lain sehingga bisa berfungsi sebagaimana mestinya. Termasuk dalam pengertian interkonektivitas adalah mencakup kemampuan interoperabilitas. Sementara yang dimaksud dengan "kompatibilitas" adalah kesesuaian Sistem Elektronik yang satu dengan Sistem Elektronik yang lainnya (Pasal 6 ayat (1) huruf a PP No. 82 Tahun 2012).

Dari sisi peraturan perundangundangan, hingga saat ini belum ada ketentuan yang secara jelas menetapkan cakupan penyelenggaraan Sistem Elektronik dalam Pemerintahan Daerah. UU No. 11 Tahun 2008 hanya menyiratkan secara sumir bahwa salah satu tujuan pemanfaatan teknologi informasi dan transaksi elektronik ( adalah untuk meningkatkan efektivitas dan efisiensi pelayanan publik, namun tidak ada elaborasi lebih lanjut tentang pelayanan publik apa saja yang perlu ditingkatkan efektivitas dan efisiensinya melalui penggunaan teknologi informasi dan transaksi elektronik (Pasal 4 huruf c UU No. 11 Tahun 2008). Ketentuan serupa juga terdapat di dalam PP No. 82 Tahun 2012, yang antara lain menyebutkan bahwa Penyelenggaraan Sistem Elektronik sebagaimana dapat dilakukan untuk pelayanan publik (Pasal 3 ayat (2) PP No. 82 Tahun 2012). Biarpun tidak mengelaborasi cakupan pelayanan publik, setidaknya PP No. 82 Tahun 2012 memuat rujukan pada ketentuan perundang-undangan terkait kriteria pelayanan publik tersebut (Pasal 3 ayat (3) PP No. 82 Tahun 2012).

Meskipun demikian, dari kajian peraturan perundang-undangan dapat diketahui bahwa ada bidang dalam Pemerintahan Daerah yang diminta oleh peraturan perundang-undangan untuk diselenggarakan dengan dukungan Sistem Elektronik, yakni pengadaan barang/jasa pemerintah. Pengadaan barang/jasa pemerintah barangkali merupakan bidang pemerintahan yang sudah memiliki dukungan Sistem Elektronik yang cukup baik pada aras praktik maupun normatif. Kondisi ini muncul dari pengaturan di bidang pengadaan barang/jasa pemerintah. Pada tingkat normatif, pengadaan barang/jasa pemerintah memiliki payung hukum di dalam Peraturan 
Presiden Nomor 54 Tahun 2010 tentang Pengadaan Barang/Jasa Pemerintah (Perpres No. 54 Tahun 2010). Meskipun pengadaan barang/jasa tidak wajib untuk dilakukan secara elektronik (Pasal 106 ayat (1) Perpres No. 54 Tahun 2010), namun tampaknya ada kecenderungan untuk menerapkan Sistem Elektronik dalam pengadaan barang/jasa pemerintah, termasuk di lingkungan Pemerintah Daerah. Kecenderungan ini juga didorong oleh pembentukan Lembaga Kebijakan Pengadaan Barang/Jasa Pemerintah (LKPP), sebuah Lembaga Pemerintah Non-Kementerian yang berfungsi mendorong terwujudnya tata-kelola pemerintahan yang baik, terutama di bidang pengadaan barang/jasa pemerintah (government procurement).

\section{Implementasi E-Government dalam Penyelenggaraan Pemerintahan Daerah}

Indonesia pada tahun 2016 menempati peringkat ke delapan dari negara-negara di dunia terkait dengan jumlah pengguna internet yang mencapai 82 juta orang (laman resmi Kementerian Komunikasi dan Informatika Republik Indonesia). Kondisi faktual ini merupakan kekuatan pendorong untuk mengimplementasikan E-Government dalam penyelenggaraan pemerintahan daerah. Dikaitkan dengan fakta tersebut maka kebutuhan untuk penyelenggaraan $E$ Government, dan perlunya pengaturan mengenai penyelenggaraan E-Government sebagai dasar hukumnya, merupakan kebutuhan yang rasional, yang memiliki koherensi dengan keberlakuan asas legalitas sebagai salah satu asas dari asas negara hukum.

Oleh karena itu, menjawab isu tentang pra-kondisi bagi implementasi $E$ Government dalam penyelenggaraan pemerintahan daerah, diperlukan suatu kerangka hukum a priori pada daerah yang hendak mengimplementasikan $E$ Government di daerahnya. Dengan pengertian lain, kerangka hukum tersebut secara lebih spesifik adalah pengaturan pada daerah, dalam hal ini melalui Peraturan Daerah. Keberadaan Peraturan Daerah tersebut koheren dengan isu perlunya legalitas implementasi E-Government dalam penyelenggaraan pemerintahan daerah.

Asas atau prinsip legalitas merupakan titik anjak untuk asas atau prinsip negara hukum. Dalam pengertian sebaliknya, berdasarkan asas atau prinsip negara hukum, pemerintah harus membentuk skema legislasi terlebih dahulu sebagai dasar tindakan (reason for action) bagi tindak-tindak pemerintahan yang hendak dilakukannya. Minimal hal itu memiliki fungsi informatoris bahwa warga negara dapat mengetahui secara jelas apa yang dapat dilakukan atau tidak oleh pemerintahnya dan bagaimana seyogianya pemerintah melakukan hal itu. Dalam pengertian demikian maka asas atau prinsip legalitas bermakna sebagai pembatasan terhadap pemerintah. Dengan keberlakuan asas legalitas maka tindak pemerintahan pada hakikatnya dikehendaki supaya bersifat reguler dan mengandung uniformitas atau keseragaman. Pada poin tersebut asas atau prinsip legalitas dari asas atau prinsip negara hukum menuntut supaya tindakan pemerintah bersifat sama dan menetap dengan secara konsisten mengikuti preskripsi dari legislasi yang berlaku umum, ketimbang mengikuti preferensi individual pejabatnya (A. Scalia, 1989).

Sebagai preskripsi untuk pengaturan ke dalam Peraturan Daerah yang hendak dilakukan, arah pengaturan Peraturan Daerah hendaknya ditujukan pada pengaturan mengenai: kewajiban dan tanggung jawab daerah dalam penyelenggaraan $E$ Government; pengelolaan sistem elektronik atau teknologi informasi dan komunikasi dalam penyelenggaraan E-Government; infrastruktur sistem elektronik atau teknologi informasi dan komunikasi untuk menerjemahkan E-Government; sumber daya manusia (SDM) sebagai operator atau pengelola dalam penyelenggaraan $E$ Government dan perlindungan terhadap sistem elektronik atau teknologi informasi dan komunikasi dalam rangka penyelenggaraan E-Government.

Hal prinsip dalam pengaturan kewajiban dan tanggung jawab pemerintah adalah supaya penyelenggaraan $E$ Government mampu mencapai tujuannya. 
Sementara dalam pengaturan mengenai pengelolaan sistem elektronik atau teknologi informasi dan komunikasi dalam penyelenggaraan $E$-Government adalah supaya penyelenggaraan E-Government dilakukan secara terpadu atau terintegrasi serta penyelenggaraan E-Government tersebut mampu 'dikendalikan' atau dikontrol. Pengaturan mengenai infrastruktur sistem elektronik atau teknologi informasi dan komunikasi adalah untuk, antara lain, menentukan jenis-jenis aplikasi yang tepat dan dibutuhkan oleh daerah sehingga hasilnya akan dapat efisien dan efektif. Pengaturan mengenai sumber daya manusia dimaksudkan supaya penyelenggaraan E-Government ditangani oleh sumber daya manusia yang kompeten dan tepat. Terakhir adalah pengaturan mengenai perlindungan terhadap sistem elektronik atau teknologi informasi dan komunikasi dalam rangka penyelenggaraan E-Government yang dimaksudkan supaya sistem tersebut aman dan tidak merugikan masyarakat maupun pemerintah sendiri.

Arah pengaturan tentang $E$ Government dalam penyelenggaraan pemerintahan daerah sebagaimana dikemukakan di atas pada hakikatnya sejalan, dan tidak bertentangan, dengan preskripsi dari peraturan perundang-undangan yang ada, khususnya UU No. 14 Tahun 2008 dan PP No. 82 Tahun 2012. Oleh karena itu, dengan menggunakan cara berpikir sistemis dari sistem peraturan perundang-undangan, preskripsi mengenai arah pengaturan tentang $E$ Government dalam penyelenggaraan pemerintahan daerah melalui Peraturan Daerah o l e h d a e rah y a n g h e d a k mengimplementasikan E-Government memiliki potensi yang kecil untuk dibatalkan karena bertentangan dengan peraturan perundang-undangan yang lebih tinggi.

Sementara secara sosiologis, dengan tingkat literasi terhadap TIK (khususnya internet) yang demikian tinggi, maka diharapkan tidak akan terjadi kesenjangan yang besar antara ekspektasi masyarakat sebagai pengguna layanan pemerintahan dengan penyelenggaraan E-Government dalam penyelenggaraan pemerintahan daerah. Dengan pengertian lain, melihat tingkat literasi terhadap teknologi informasi yang tinggi maka akan diikuti pula oleh efektivitas dalam penyelenggaraan E-Government serta pengaturan mengenai penyelenggaraan $E$ Government-nya itu sendiri. Oleh karena itu, pengaturan demikian akan sejalan dengan asas dalam pembentukan peraturan perundangundangan yang baik yaitu asas dapat dilaksanakan (yang artinya: setiap pembentukan peraturan perundang-undangan harus memperhitungkan efektivitas peraturan perundang-undangan tersebut di dalam masyarakat). serta asas kedayagunaan dan kehasilgunaan (Yang artinya: setiap peraturan perundang-undangan dibuat karena memang benarbenar dibutuhkan dan bermanfaat dalam mengatur kehidupan bermasyarakat, berbangsa, dan bernegara). Hal ini juga sejalan dengan teori pengaturan yang dikemukakan oleh Bronwen Morgan dan Karen Yeung yang menyatakan bahwa instrumen regulasi seyogianya memiliki daya persuasi yang bernalar sehingga mendorong penerimaan masyarakat atas instrumen itu, tanpa perlu dipaksakan (B. Morgan \& K. Yeung, 2007).

\section{Simpulan}

Berdasarkan hasil pembahasan di atas dapat dirumuskan kesimpulan sebagai berikut:

1. Secara teoretis, E-Government dalam penyelenggaraan pemerintahan daerah didukung oleh konsepsi Hukum Administrasi Baru yang lebih menekankan aspek keterbukaan atau transparansi dan efisiensi dalam pemerintahan.

2. Secara yuridis, meskipun belum terdapat Undang-Undang yang secara khusus mengatur tentang E-Government, sudah terdapat kerangka hukum berupa peraturan perundang-undangan pada tingkat nasional atau pusat sebagai dasar bagi daerah untuk mengimplementasikan E-Government dalam penyelenggaraan pemerintahan daerah.

3. Preskripsi sebagai saran tindak bagi $\mathrm{d}$ a e r a h d a 1 a m r a n g k a mengimplementasikan E-Government dalam penyelenggaraan pemerintahan daerah, perlunya daerah untuk mempersiapkan kerangka hukum guna keterpenuhan asas legalitas bagi kebijakannya tersebut. 


\section{DAFTAR PUSTAKA}

Cane, P. (2011). Administrative Law. Oxford: Oxford University Press.

Darumurti, K.D. (2012). Kekuasaan Diskresi Pemerintah. Bandung: PT. Citra Aditya Bakti.

Douglas, R. (1998). Administrative Law and Good Government. In Samford, C., \& Preston, N. (Eds.), Public Sector Ethics: Finding and Implementing Values. (pp. 122-136). London: Routledge.

Hadjon, P.M. (1987). Perlindungan Hukum bagi Rakyat di Indonesia. Surabaya: Penerbit Bina Ilmu.

Kjaer, M., \& Kinnerup, K. (2002). Good Governance: How Does It Relate to Human Rights? In Sano Hans-Otto., \& Alfredson, G. (Eds.), Human Rights and Good Governance. (pp. 1-18). The Hague: Martinus Nijhoff Publishers.

Kubicek, H., et.al. (2011). Organizational Inter-Operability in E-Government: Lessons from 77 European GoodPractice Cases. Berlin: Springer.

Lucchi, N. (2016). The Impact of Science and Technology on the Rights of the Individual. Switzerland: Springer.

Naskah Akademik Rancangan UndangUndang tentang Penyelenggaraan Sistem Elektronik untuk Administrasi Pemerintahan dan Pelayanan Publik (Versi 19 Mei 2014). Retrieved from $<\mathrm{h} \mathrm{t} \mathrm{t} \mathrm{p} \mathrm{s} \mathrm{:} \mathrm{/} \mathrm{/} \mathrm{w} \mathrm{w} \mathrm{w} \mathrm{.} \mathrm{m} \mathrm{e} \mathrm{n} \mathrm{p} \mathrm{a} \mathrm{n.}$ go.id/download/file/5002-20150827naskah-akademik-ruu-egov-19-mei2014>.

McCoubrey, H., \& White, N. D., (1996). Textbook on Jurisprudence. London: Blackstone Press Ltd.

Morgan, B., \& Yeung, K. (2007). An Introduction to Law and Regulation: Text and Materials. Cambridge: Cambridge University Press.

OECD Guiding Principles for Open and Inclusive Policy Making: Background Document for Session 1, Expert Meeting on 'Building and Innovative Government for Better Policies and Service Delivery, Paris, 8-9 Juni 2010. Retrieved from <http://www. oecd.org/gov/46560128.pdf>.

Pimple, K.D. (2014). Introduction: The Impacts, Benefits and Hazards of PICT. In K.D. Pimple (Ed.), Emerging Pervasive Information and Communication Technologies (PICT): Ethical Challenges, Opportunities and Safeguards. (pp. 1-12). Dordrecht: Springer.

Scalia, A. (1989). The Rule of Law as a Law of Rules. The University of Chicago Law Review, Vol. 56 (No. 4), pp. 11751188.

So, B. (2003). Public Parcipation in South and North Korean Environmental Laws, SJD Dissertation (Disertasi di Bidang Doktor Ilmu Hukum), School of Law, Pace University.

\section{Peraturan Perundang-undangan}

Undang-Undang Nomor 14 Tahun 2008 tentang Informasi dan Transaksi Elektronik.

Undang-Undang Nomor 23 Tahun 2014 tentang Pemerintahan Daerah.

Undang-Undang Nomor 30 Tahun 2014 tentang Administrasi Pemerintahan.

Peraturan Pemerintah No. 82 Tahun 2012 tentang Penyelenggaraan Sistem dan Transaksi Elektronik.

Peraturan Presiden Nomor 54 Tahun 2010 tentang Pengadaan Barang/Jasa Pemerintah. 